\title{
ACTIVE TRANSPORT OF THIAMINE FROM RAT SMALL INTESTINE
}

\author{
Toru KomaI, Kenji KawaI, and Hideyo SHINDO ${ }^{1}$ \\ Central Research Laboratories, Sankyo Co., Ltd., Shinagawa-ku, Tokyo 140
}

(Received April 18, 1974)

\begin{abstract}
The tissue accumulation method was ascertained to be a more suitable method for studying the intestinal absorption mechanism in vitro than the everted sac method. By means of the tissue accumulation method, the absorption mechanism of thiamine from the rat small intestine was investigated. The ratio of intracellular to extracellular concentration was found to exceed unity with respect to free thiamine, indicating that thiamine is transported against a concentration gradient. Then, thiamine uptake by the intestinal segments was saturable and dependent on the incubation temperature. The transport required metabolic energy and was inhibited by pyrithiamine and chloroethylthiamine competitively. These evidences indicate that thiamine is absorbed from the rat small intestine by active transport.

Chloroethylthiamine, which has no inhibitory effect on thiamine pyrophosphokinase, inhibited thiamine transport. Moreover, thiamine pyrophosphokinase was scarecely detected in microvillous membrane.

The longitudinal distribution of thiamine pyrophosphokinase activity along the digestive tract did not coincide with that of the activity of thiamine uptake. These results indicate that there is a carrier system for thiamine transport which is not dependent upon the phosphorylation process in the rat small intestine.
\end{abstract}

Since the observation by MORRISON et al. (1) that thiamine absorption is saturable when orally administered to human subjects, it has been suggested that a specific mechanism other than passive diffusion participates in thiamine transport from the small intestine. Recently we examined thiamine absorption from the chick intestine and revealed that thiamine is actively transported against a concentration gradient at a physiological concentration (2).

RINDI et al. (3-5) have studied the thiamine absorption from the rat small

1 駒井 亨, 河合賢司, 進藤英世

Abbreviations used: PPO, 2,5-diphenyloxazole; dimethyl-POPOP, dimethyl-2,2'-p-phenylene-bis-(5-phenyloxazole). 
intestine, using the everted sac technique in vitro, and concluded that thiamine is actively absorbed. It has not been sufficiently demonstrated, however, that thiamine is transported against a concentration gradient with respect to free thiamine species because of the rapid pyrophosphorylation of thiamine in the tissue before appearance in the serosal fluid.

In this paper, thiamine transport by the rat small intestine was studied kinetically in detail using the in vitro tissue accumulation method developed by AgAR et al. (6). Prior to the investigation, it was ascertained that this method is more suitable to studying the kinetics of thiamine transport than the everted sac technique and that the tissue maintains its histological rigidity during the experiments.

The results revealed that thiamine is taken up by the rat small intestine by an active transport and that there exists a carrier system which is distinguishable from the system for thiamine pyrophosphorylation.

\section{EXPERIMENTAL}

Materials. ${ }^{35}$ S-Thiamine was purchased from Radiochemical Center, Amersham, England. The specific activity was 230 to $470 \mu \mathrm{Ci} / \mathrm{mg}$ and the radiochemical purity was ascertained to be over $98 \%$ by thin layer chromatography. ${ }^{14} \mathrm{C}$-Inulin was also purchased from Radiochemical Center and the specific activity was $2.72 \mu \mathrm{Ci} / \mathrm{mg}$. Chloroethylthiamine was prepared by thiothiamine method $(7,8)$. Other chemicals were of reagent grade and were used without further purification.

Experiments on thiamine uptake by the everted sac technique. Male WistarImamichi rats weighing 200 to $250 \mathrm{~g}$ were used after fasting for $16 \mathrm{hr}$. The animals were killed by decapitation, the abdomen opened and the intestines quickly removed, washed with $0.9 \% \mathrm{NaCl}$ solution and everted with a stainless steel probe. The segments, about $8 \mathrm{~cm}$ in length of the everted upper small intestines, were filled with $0.6 \mathrm{ml}$ of Krebs-Henseleit bicarbonate buffer (9) containing $0.3 \%$ glucose and preliminarily gassed with $95 \% \mathrm{O}_{2}-5 \% \mathrm{CO}_{2}$. Each sac was placed in a $100 \mathrm{ml}$ Erlenmeyer flask with $15 \mathrm{ml}$ of the same buffer. After $10 \mathrm{~min}$ preincubation at $37^{\circ} \mathrm{C},{ }^{35} \mathrm{~S}$-thiamine was added into the medium. The flask was gassed with $95 \% \mathrm{O}_{2}-5 \% \mathrm{CO}_{2}$ for $1 \mathrm{~min}$, stoppered and incubated in an oscillating water bath at $37^{\circ} \mathrm{C}$. At the end of the incubation the sac was weighed before and after emptying the content and the difference in weight was taken as the amount of serosal fluid. The concentrations of ${ }^{35} \mathrm{~S}$-thiamine in both the serosal and mucosal fluids were determined by counting the radioactivity of an aliquot with a liquid scintillation counter. For determining the radioactivity accumulated in the tissue, the tissue was homogenized in $15 \%$ trichloroacetic acid with a PotterElvehjem homogenizer and centrifuged at $10,000 \mathrm{rpm}$ for $10 \mathrm{~min}$. The precipitates were extracted twice with $5 \%$ trichloroacetic acid and the supernatants were combined. The radioactivity was counted with a liquid scintillation counter. 
Experiments on thiamine uptake by tissue accumulation method. The rat small intestine everted as described above was cut into rings of 3-5 mm length. About $0.6 \mathrm{~g}$ of the everted rings were randomly tranferred to a $100 \mathrm{ml}$ Erlenmeyer flask with $15 \mathrm{ml}$ of Krebs-Henseleit bicarbonate buffer containing $0.3 \%$ glucose. After preincubation for $10 \mathrm{~min}$ at $37^{\circ} \mathrm{C}$ under gassing with $95 \% \mathrm{O}_{2}-5 \% \mathrm{CO}_{2},{ }^{85} \mathrm{~S}$-thiamine was added and the flask with a rubber stopper was incubated for $30 \mathrm{~min}$ at $37^{\circ} \mathrm{C}$ under constant oscillation of 80 times $/ \mathrm{min}$. After the incubation, the medium was poured off and the segments were rinsed three times with ice-chilled buffer, gently blotted on a filter paper and weighed. The extraction of the radioactive substances from the segments and determination of the radioactivity were done as described in the everted sac technique.

The total tissue water was determined to be $81.24 \pm 0.86 \%$ of the wet weight after $30 \mathrm{~min}$ incubation, from the difference between the wet tissue weight and the weight after drying at $90^{\circ} \mathrm{C}$ for $24 \mathrm{hr}$. The extracellular space was determined with ${ }^{14} \mathrm{C}$-inulin, and the intracellular space and the concentration of thiamine in intracellular fluid $\left(C_{\mathrm{ICF}}\right)$ were calculated, as previously described (2).

Determination of free ${ }^{35} S$-thiamine and its phosphates in tissue and medium. The incubation media or the extracts from the tissue were charged on a charcoal

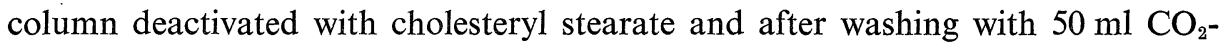
free water the adsorbed radioactivity was eluted with $75 \mathrm{ml}$ of $10 \%$ propanol in $0.1 \mathrm{~N} \mathrm{HCl}$. After concentrating the eluate in vacuo at $35^{\circ} \mathrm{C}$, a portion was spotted on Toyo-Roshi No. 51 and developed along with authentic thiamine and thiamine mono-, di- and triphosphate. The solvent system used was $n$-propanol: water: $1 \mathrm{M}$ acetate buffer ( $\mathrm{pH}$ 5.0) (7:2:1, by volume). After developing, each spot was detected with the thiochrome reaction by spraying ferricyanide solution in alkaline alcohol and extracted from the paper with $0.1 \mathrm{~N} \mathrm{HCl}$. The radioactivity was then determined with a liquid scintillation counter.

Absorption form of ${ }^{35} S$-thiamine in portal blood. Male Wistar-Imamichi rats weighing $280 \mathrm{~g}$ were used after fasting for $16 \mathrm{hr}$. The rats were anesthetized with intraperitoneal injection of pentobarbital $(50 \mathrm{mg} / \mathrm{kg})$ and the middle part of the small intestines were ligated at two positions in about 8-cm lengths without stopping the blood flow. After a polyethylene tube was cannulated into the portal vein, $10 \mu \mathrm{g}$ of ${ }^{35} \mathrm{~S}$-thiamine was injected into the ligated loop in situ. The portal blood was collected into a centrifuge tube. At $30 \mathrm{~min}$ after the injection, the radioactivity in the portal blood and the intestinal tissue was extracted twice with $15 \%$ and $5 \%$ trichloroacetic acid. The radioactive substances were separated by paper chromatography as described above.

Determination of thiamine pyrophosphokinase activity in different parts of rat digestive tract. For the examination of the longitudinal distribution of thiamine pyrophosphokinase along the digestive tract of rats, $5-\mathrm{cm}$ lengths of each part of the digestive tract was homogenized with 5 volumes of $1.15 \% \mathrm{KCl}$ in PotterElvehjem homogenizer, and centrifuged at $9,000 \times g$ for $20 \mathrm{~min}$ at $0^{\circ} \mathrm{C}$ and the 
supernatant was used as the enzyme extract. The reaction mixture contained $50 \mu \mathrm{M}$ of Tris buffer (pH 7.4), $1 \mathrm{mM}$ of ATP, $3.3 \mathrm{mM}$ of $\mathrm{MgSO}_{4}, 0.1 \mathrm{~mm}^{35} \mathrm{~S}$-thiamine and $1 \mathrm{ml}$ of the supernatant. After incubation for $30 \mathrm{~min}$ at $37^{\circ} \mathrm{C}$, the reaction mixture was boiled for $2 \mathrm{~min}$ and centrifuged. ${ }^{35} \mathrm{~S}$-Thiamine pyrophosphate formed was separated and determined by paper chromatography as described above.

Determination of subcellular distribution of thiamine pyrophosphokinase. In order to determine the subcellular distribution of thiamine pyrophosphokinase in the intestine, the intestinal mucosa was scrapped with a glass slide from the upper part of the small intestine of rats fasted for $16 \mathrm{hr}$ and homogenized in $0.25 \mathrm{M}$ sucrose with a Politron Homogenizer for 1 min followed by centrifugation at $900 \times g$ for $10 \mathrm{~min}$. Mitochondria were precipitated after centrifugation of the supernatant at $9,000 \times g$ for $20 \mathrm{~min}$, and the supernatant was subsequently centrifuged at $105,000 \times g$ for $60 \mathrm{~min}$ to separate the microsomes from soluble fraction. Thiamine pyrophosphokinase activity of each fraction was determined as mentioned above. Leucine amino peptidase, one of the marker enzymes of microvillous membrane, was determined by the formation of naphthylamine from L-leucyl naphthylamide.

Histological examination. In order to ascertain the tissue preservation, everted ring segments were incubated in Krebs-Henseleit bicarbonate buffer for 0, 10 and $30 \mathrm{~min}$. After incubation, the segments were fixed with Carnoy's reagents for $60 \mathrm{~min}$ at room temperature, embedded in paraffin and cut into $4 \mu$-thick sections. All sections were stained with haematoxyline and eosin, and examined microscopically.

Determination of radioactivity. For the determination of radioactivity, usually $0.5 \mathrm{ml}$ of a sample was pipetted into a counting vial containing $15 \mathrm{ml}$ of liquid scintillator $(800 \mathrm{ml}$ dioxane, $200 \mathrm{ml}$ toluene, $8 \mathrm{~g}$ POP, $200 \mathrm{mg}$ dimethylPOPOP). The radioactivity was counted with a Packard Tri-Carb 3214 liquid scintillation counter. The counting efficiency was determined by an internal standard method with ${ }^{14} \mathrm{C}$-toluene.

\section{RESULTS}

Thiamine transport with an everted intestinal sac

The everted sacs of the rat small intestine, which contain no thiamine in the serosal fluids, were incubated in the medium containing $0.21 \mu \mathrm{g} / \mathrm{ml}$ of ${ }^{35} \mathrm{~S}$ thiamine at $37^{\circ} \mathrm{C}$ and the time course of thiamine transport through the intestinal tissue were examined. As shown in Table 1 and Fig. 1, the radioactivity was not detected in the serosal fluid $5 \mathrm{~min}$ after incubation at all, and a trace amount of radioactive substances was observed after $10 \mathrm{~min}$. The ratio of the concentration of radioactive substances in the serosal fluid to that in the medium did not exceed 1.0 until $1 \mathrm{hr}$ after incubation. On the contrary, thiamine accumula- 
tion in the tissue occurred very rapidly. The concentration of radioactive substances in the tissue became the same level as that in the medium 10 min after incubation and more than 3 times of the medium concentration after $1 \mathrm{hr}$. This result indicates that the process of thiamine efflux from the tissue to the serosal side is rate limiting. Thus, it was considered that it is more convenient for the in vitro investigation of thiamine transport to examine thiamine movement from the medium to the tissue rather than that from the medium to the serosal fluid.

Table 1. ${ }^{35} \mathrm{~S}-\mathrm{Thiamine}$ transport by everted intestinal sacs of rats. ${ }^{\mathrm{a}}$

\begin{tabular}{|c|c|c|c|c|c|}
\hline \multirow{2}{*}{$\begin{array}{l}\text { Incubation } \\
\text { times } \\
\text { (min) }\end{array}$} & \multicolumn{3}{|c|}{ Concentration of ${ }^{35} \mathrm{~S}$-substances in } & \multicolumn{2}{|c|}{ Concentration ratio } \\
\hline & $\begin{array}{l}\text { Medium (M) } \\
(\mu \mathrm{g} / \mathrm{ml})\end{array}$ & $\begin{array}{c}\text { Tissue (T) } \\
(\mu \mathrm{g} / \mathrm{g} \pm \text { S.E. })\end{array}$ & $\begin{array}{l}\text { Serosa (S) } \\
(\mu \mathrm{g} / \mathrm{ml})\end{array}$ & $\mathrm{T} / \mathrm{M}$ & $\begin{array}{l}\text { n ratio } \\
\text { S/M }\end{array}$ \\
\hline 5 & $0.208^{b}$ & $0.146 \pm 0.020$ & 0 & 0.70 & 0 \\
\hline 10 & 0.210 & $0.214 \pm 0.047$ & 0.012 & 0.98 & 0.05 \\
\hline 20 & 0.203 & $0.392 \pm 0.053$ & 0.026 & 1.88 & 0.13 \\
\hline 30 & 0.208 & $0.584 \pm 0.047$ & 0.056 & 2.81 & 0.27 \\
\hline 60 & 0.195 & $0.667 \pm 0.127$ & 0.140 & 3.42 & 0.72 \\
\hline 90 & 0.197 & $0.836 \pm 0.082$ & 0.312 & 4.24 & 1.58 \\
\hline 120 & 0.174 & $0.942 \pm 0.032$ & 0.325 & 5.41 & 1.87 \\
\hline 180 & 0.188 & $1.389 \pm 0.331$ & 0.403 & 7.39 & 2.14 \\
\hline 240 & 0.169 & $1.157 \pm 0.164$ & 0.428 & 6.85 & 2.53 \\
\hline
\end{tabular}

a Everted sacs of the rat small intestine were incubated with $0.21 \mu \mathrm{g} / \mathrm{ml}{ }^{35} \mathrm{~S}$-thiamine at $37^{\circ} \mathrm{C}$ for the indicated times. Other details are described in ExPERIMENTAL.

$\mathrm{b}$ Each value represents the average from 3 experiments.

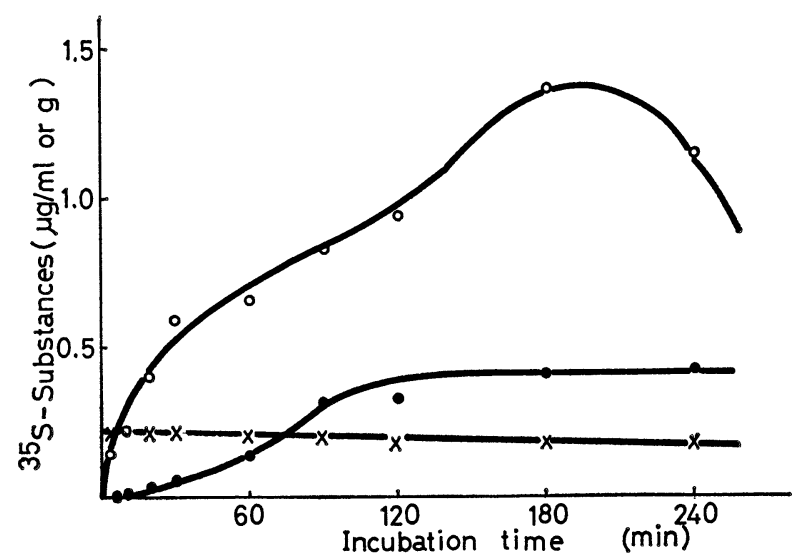

Fig. 1. Time course of ${ }^{35}$ S-thiamine transport by everted sacs of the rat small intestine. Everted sacs were incubated with $0.21 \mu \mathrm{g} / \mathrm{ml}{ }^{35} \mathrm{~S}$-thiamine at $37^{\circ} \mathrm{C}$ for various periods as indicated, and the concentration of thiamine in the medium $(x-x)$, in the tissue $(0-0)$ and in the serosal fluid (-) was determined as described in ExPERIMENTAL. Each point represents the mean of three experiments. 
A

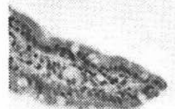

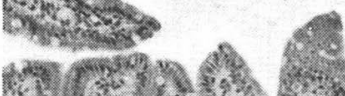

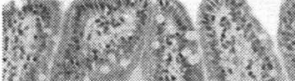

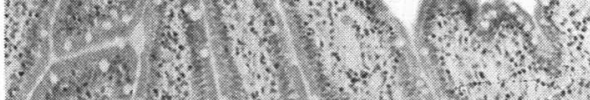

2.

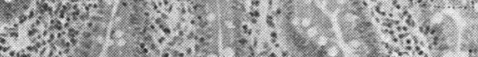

Fi:3:3:

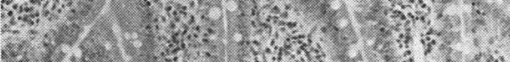

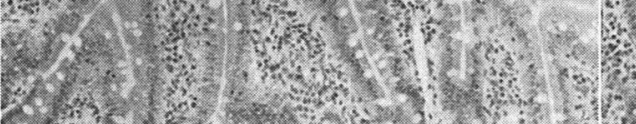

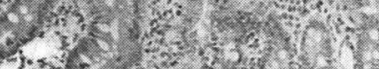

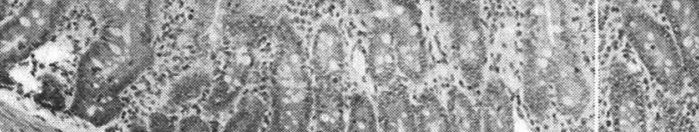

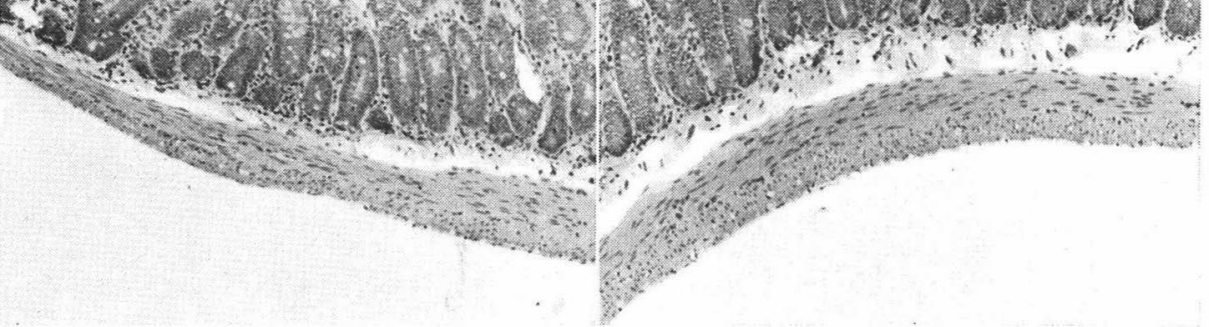

C

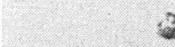

3

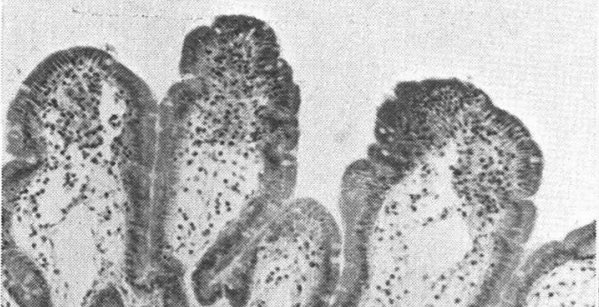

D

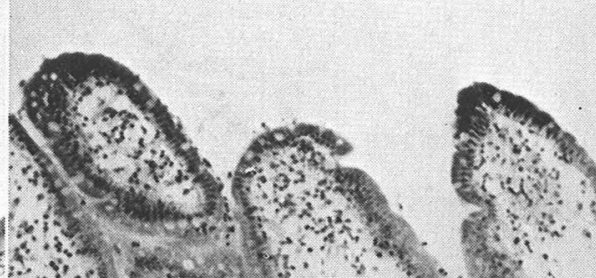

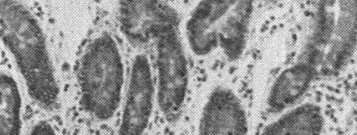

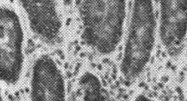

30

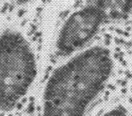

$3.26 y^{2}$
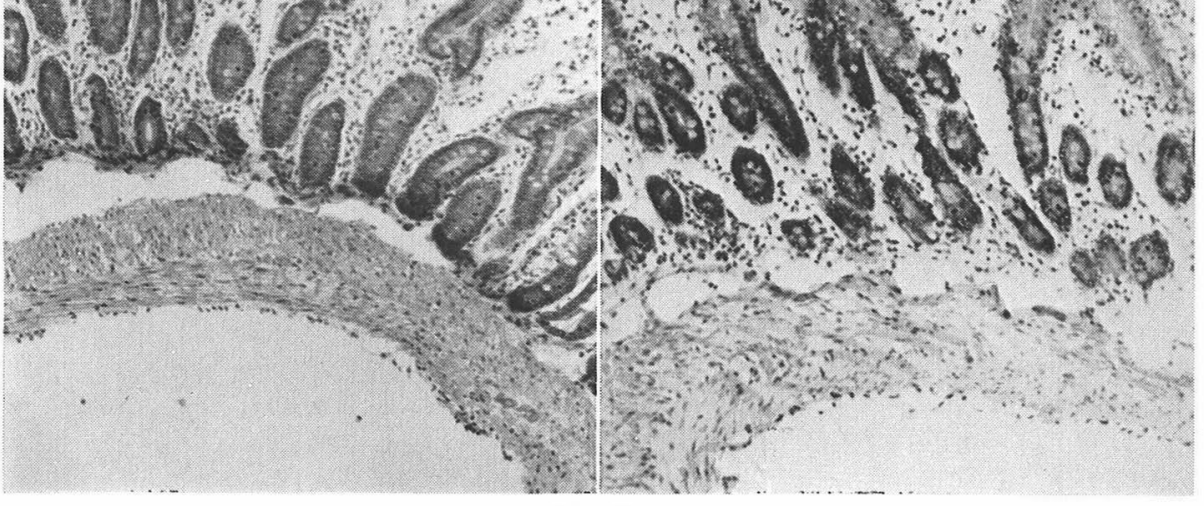

Fig. 2. 


\section{Histological examination on preservation of tissue rigidity}

In the reevaluating the everted sac technique, LEVINE et al. (10) showed a significant disruption of the epithelial lining cells of the sacs even $15 \mathrm{~min}$ after incubation. Thus, prior to investigation of the thiamine transport with tissue accumulation method, the preservation of tissue rigidity was examined histologically after incubation of ring segments of the rat small intestine in Krebs-Henseleit bicarbonate buffer.

Figure 2-A and 2-B show the small intestine immediately before and after eversion, respectively. No disruption of the epithelial lining cells was observed by the treatment. Figure 2-C shows the tissue incubated for $10 \mathrm{~min}$ and Fig. 2$\mathrm{D}$ for $30 \mathrm{~min}$ at $37^{\circ} \mathrm{C}$. Although the edma in lamina propria became larger according to the increase of incubation time, the figure of villi did not change for $10 \mathrm{~min}$ and the absorptive epithelial cells were sufficiently preserved after incubation for $30 \mathrm{~min}$.

\section{Uptake and accumulation of ${ }^{35}$ S-thiamine by rat intestinal segments}

The in vitro uptake of thiamine by rat intestinal segments was examined in the different initial concentration of ${ }^{35} \mathrm{~S}$-thiamine in the medium. The results revealed that the rate of uptake increased markedly with decreasing thiamine concentration in the medium as shown in Fig. 3 and, as listed in Table 2, the intracellular to extracellular concentration ratio $\left(C_{\mathrm{ICF}} / C_{\mathrm{ECF}}\right)$ after $30 \mathrm{~min}$ of incubation was higher than unity even when the initial concentration was $1.2 \mu \mathrm{g} /$ $\mathrm{ml}$, and increased to 4.33 and 6.28 according to the decrease of the concentration to 0.2 and $0.1 \mu \mathrm{g} / \mathrm{ml}$, respectively.

Figure 4 shows the time course of ${ }^{35} \mathrm{~S}$-thiamine uptake with the initial concentration of $0.2 \mu \mathrm{g} / \mathrm{ml}$. After a rapid increase in the uptake during the first $30 \mathrm{~min}$, a steady state level was observed. The concentration ratio exceeded 1.0 after $10 \mathrm{~min}$ and attained 3.97 after $30 \mathrm{~min}$.

The accumulation of radioactivity against the concentration gradient, however, cannot justify an active transport of thiamine, because it is possible that ${ }^{35} \mathrm{~S}$ thiamine undergoes phosphorylation during or after the transport process. Therefore, the concentration of free ${ }^{35} \mathrm{~S}$-thiamine in the tissue and the medium were determined after incubation with $0.2 \mu \mathrm{g} / \mathrm{ml}{ }^{35} \mathrm{~S}$-thiamine for $30 \mathrm{~min}$ at $37^{\circ} \mathrm{C}$. As shown in Table $3,42.0 \%$ of the total radioactivity in the tissue and $93.3 \%$ of the total radioactivity in the medium were found to be free thiamine. Thus, it is indicated that the tissue to medium concentration ratio with respect to free

Fig. 2. Everted ring segments of rat small intestine. The rat small intestine was everted with a stainless steel probe, cut into rings of 3-5 mm length and incubated in KrebsHenseleit bicarbonate buffer. After incubation the segments were fixed, sectioned and stained with haematoxylin-eosin as described in EXPERIMENTAL. A, Small intestine before eversion; B, Small intestine after eversion; C, Everted ring segments incubated for $10 \mathrm{~min}$; D, Everted ring segments incubated for $30 \mathrm{~min}$. (A, B, $\times 120 ; \mathrm{C}, \mathrm{D}, \times$ 150) 
Table 2. Relationship between ${ }^{35} \mathrm{~S}$-thiamine uptake by rat intestinal segments and initial medium concentration of thiamine. ${ }^{\mathrm{a}}$

\begin{tabular}{cccc}
\hline $\begin{array}{c}\text { Initial concentration } \\
\text { of thiamine } \\
(\mu \mathrm{g} / \mathrm{ml})\end{array}$ & $\begin{array}{c}\text { Concentration of } \\
\text { in medium } \\
(\mu \mathrm{g} / \mathrm{ml})\end{array}$ & $\begin{array}{c}{ }^{55} \text {-substances } \\
\text { in tissue } \\
(\mu \mathrm{g} / \mathrm{ml} \text { ICF } \pm \text { S.E. })\end{array}$ & $\begin{array}{c}\text { Ratio } \\
\text { tissue/medium }\end{array}$ \\
\hline 0.1 & $0.095^{\mathrm{b}}$ & $0.594 \pm 0.035$ & 6.28 \\
0.2 & 0.194 & $0.839 \pm 0.072$ & 4.33 \\
0.4 & 0.401 & $1.140 \pm 0.023$ & 2.84 \\
0.8 & 0.790 & $1.393 \pm 0.040$ & 1.76 \\
1.2 & 1.225 & $1.471 \pm 0.017$ & 1.20 \\
\hline
\end{tabular}

a The rat small intestinal segments were incubated with ${ }^{35} \mathrm{~S}$-thiamine at $37^{\circ} \mathrm{C}$ for $30 \mathrm{~min}$. Other experimental details for the determination of uptake are described in ExPERIMENTAL.

${ }^{b}$ Each value represents the average from more than 4 experiments.

Table 3. Concentration ratio of free thiamine after ${ }^{35} \mathrm{~S}$-thiamine uptake by rat small intestinal segments. ${ }^{\mathrm{a}}$

\begin{tabular}{|c|c|c|c|}
\hline & & \multicolumn{2}{|c|}{ Thiamine concentration } \\
\hline & & Total thiamine & Free thiamine \\
\hline Tissue & $(\mu \mathrm{g} / \mathrm{ml} \mathrm{ICF})$ & $0.989^{b}$ & 0.416 \\
\hline Medium & $(\mu \mathrm{g} / \mathrm{ml})$ & 0.196 & 0.183 \\
\hline Ratio & (tissue/medium) & 5.05 & 2.27 \\
\hline
\end{tabular}

a Everted ring segments of the rat small intestine were incubated with $0.2 \mu \mathrm{g} / \mathrm{ml}{ }^{35} \mathrm{~S}$ thiamine for $30 \mathrm{~min}$ at $37^{\circ} \mathrm{C}$. Other details are described in EXPERIMENTAL.

${ }^{b}$ Each value represents the average from 3 experiments.

thiamine species also exceeds unity, being 2.27 .

\section{Effect of temperature on thiamine uptake}

As shown in Table 4, the lowering of the incubation temperature caused a marked decrease in the rate of thiamine uptake. When the temperature was lowered to $25^{\circ} \mathrm{C}$ and $4^{\circ} \mathrm{C}$, the uptake of ${ }^{35} \mathrm{~S}$-thiamine was reduced to 15.5 and $4.4 \%$ of that at $37^{\circ} \mathrm{C}$, respectively. The intracellular to extracellular concentration ratio after incubation at $4^{\circ} \mathrm{C}$ for $30 \mathrm{~min}$ was only 0.18 in contrast to 4.02 at $37^{\circ} \mathrm{C}$. .

\section{Effect of metabolic inhibitors on thiamine uptake}

As shown in Table 5, the uptake of ${ }^{35}$ S-thiamine by the intestinal segments was markedly inhibited by metabolic inhibitors and by an anaerobic condition. These results indicate that the concentrative uptake of thiamine is dependent on energy which is supplied by oxidative phosphorylation.

\section{Effect of thiamine analogues on thiamine uptake}

The effect of 10 and 100 times amounts of thiamine analogues on the thiamine 


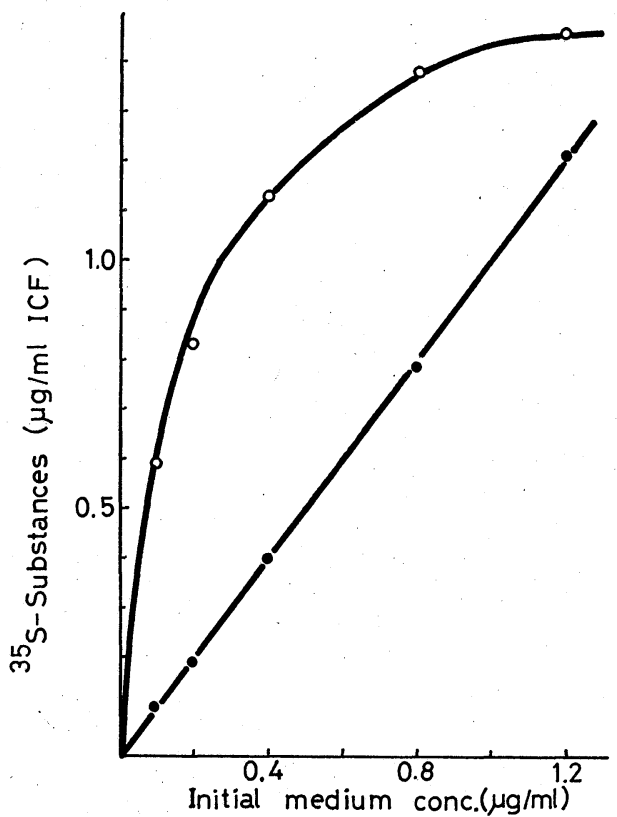

Fig. 3. Relationship between ${ }^{35} \mathrm{~S}$-thiamine uptake by everted intestinal rings of the rat and initial medium concentration of thiamine. The tissue was incubated with ${ }^{35} \mathrm{~S}-$ thiamine at $37^{\circ} \mathrm{C}$ for $30 \mathrm{~min}$. $\bigcirc-\bigcirc,{ }^{35} \mathrm{~S}$-thiamine concentration in the intracellular fluid (ICF) of the tissue; - - , initial ${ }^{35} \mathrm{~S}$-thiamine concentration in the medium.

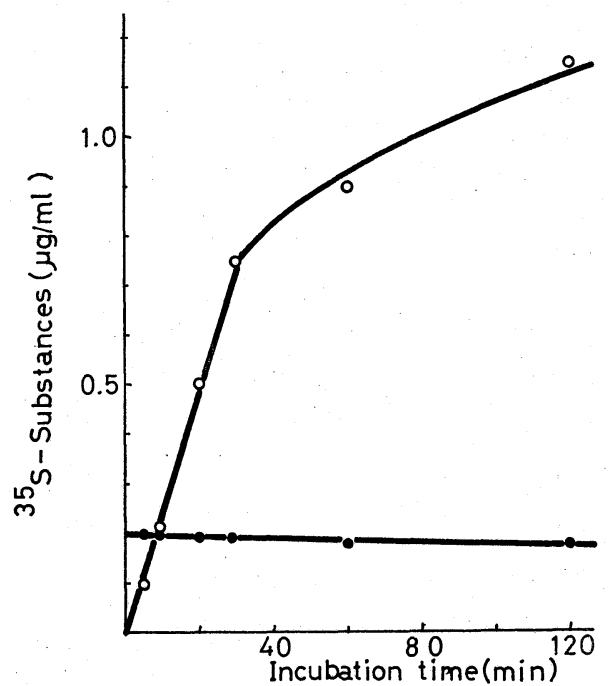

Fig. 4. Time course of ${ }^{35} \mathrm{~S}$-thiamine uptake by everted intestinal rings of the rat. The tissue was incubated with $0.2 \mu \mathrm{g} / \mathrm{ml}{ }^{35} \mathrm{~S}$-thiamine at $37^{\circ} \mathrm{C}$ for various periods as indicated. The results are expressed as ${ }^{35} \mathrm{~S}$-substance concentration in the intracellular fluid of the tissue $(\mathrm{O}-\mathrm{O})$ and in the medium (-). Each point represents the mean of three determinations. 
Table 4. Effect of incubation temperature on thiamine uptake. ${ }^{\mathrm{a}}$

\begin{tabular}{cccc}
\hline $\begin{array}{c}\text { Incubation } \\
\text { temperature }\left({ }^{\circ} \mathrm{C}\right)\end{array}$ & $\begin{array}{c}\text { Tissue concentration } \\
(\mu \mathrm{g} / \mathrm{ml} \mathrm{ICF} \pm \text { S.E. })\end{array}$ & $\begin{array}{c}\text { Uptake ratio } \\
C_{\mathrm{ICF}} / C_{\mathrm{ECF}}\end{array}$ & $\begin{array}{c}\text { Per cent } \\
\text { decrease }\end{array}$ \\
\hline 37 & $0.805 \pm 0.071^{\mathrm{b}}$ & 4.02 & 0 \\
25 & $0.125 \pm 0.014$ & 0.62 & 84.5 \\
4 & $0.035 \pm 0.002$ & 0.18 & 95.6 \\
\hline
\end{tabular}

a The rat intestinal ring segments were incubated with $0.2 \mu \mathrm{g} / \mathrm{ml}{ }^{35} \mathrm{~S}$-thiamine for $30 \mathrm{~min}$. Other experimental details are described in EXPERIMENTAL.

${ }^{b}$ Each value represents the average from 4 experiments.

Table 5. Effect of metabolic inhibitors and anaerobic condition on thiamine uptake. ${ }^{\mathrm{c}}$

\begin{tabular}{lcccc}
\hline \multirow{2}{*}{ Inhibitor } & $\begin{array}{c}\text { Concentration } \\
\text { (M) }\end{array}$ & \multicolumn{2}{c}{$\begin{array}{c}\text { Uptake ratio } \\
\left(C_{\mathrm{ICF}} / C_{\mathrm{ECF}}\right)\end{array}$} & $\begin{array}{c}\text { Per cent } \\
\text { inhibition }\end{array}$ \\
\cline { 3 - 4 } & & Control & Treated & \\
\hline $\mathrm{DNP}^{\mathrm{a}}$ & $10^{-3}$ & $4.31^{\mathrm{d}}$ & 0.98 & 71.4 \\
& $10^{-4}$ & 5.05 & 2.26 & 51.8 \\
$\mathrm{MIA}^{\mathrm{b}}$ & $10^{-3}$ & 5.22 & 1.48 & 65.1 \\
& $10^{-4}$ & 4.31 & 1.82 & 52.3 \\
$\mathrm{NaN}_{3}$ & $10^{-3}$ & 4.31 & 1.14 & 68.3 \\
& $10^{-4}$ & 4.31 & 1.86 & 52.0 \\
$\mathrm{NaF}$ & $10^{-2}$ & 2.89 & 1.16 & 54.7 \\
& $10^{-3}$ & 4.31 & 2.34 & 41.3 \\
aerobic & $95 \% \mathrm{O}_{2}$ & 2.89 & & \\
anaerobic & $95 \% \mathrm{~N}_{2}$ & & 1.25 & 56.3 \\
\hline
\end{tabular}

a DNP, 2,4-Dinitrophenol; $\quad{ }^{\mathrm{b}} \mathrm{MIA}=$ Monoiodoacetic acid.

c The rat small intestinal segments were incubated in $15 \mathrm{ml}$ buffer containing $0.2 \mu \mathrm{g} / \mathrm{ml}$ ${ }^{35} \mathrm{~S}$-thiamine with or without inhibitors at $37^{\circ} \mathrm{C}$ for $30 \mathrm{~min}$ under $95 \% \mathrm{O}_{2}-5 \% \mathrm{CO}_{2}$ atmosphere. In anaerobic condition, $95 \% \mathrm{~N}_{2}$ was used in place of $95 \% \mathrm{O}_{2}$.

d Each value represents the average from 4 experiments.

uptake is shown in Table 6. Although pyrithiamine and oxythiamine are both typical antithiamine compounds, the latter showed much weaker inhibitory action than the former. In the presence of pyrithiamine 10 and 100 times to the initial thiamine concentration, the thiamine uptake was inhibited by 87.28 and $94.91 \%$, respectively. Chloroethylthiamine, thiamine monophosphate and thiamine pyrophosphate also inhibited the thiamine uptake markedly, in almost the same extent as pyrithiamine.

In order to clarify the nature of inhibitions, the uptake of thiamine at various concentrations in absence or presence of a constant amount of pyrithiamine or chloroethylthiamine was examined. As shown in Fig. 5, the LineweaverBurk plots showed that both pyrithiamine and chloroethylthiamine inhibit the thiamine uptake competitively and the following $K_{m}$ and $K_{i}$ values were obtained: $K_{m}$ for thiamine transport, $0.59 \times 10^{-6} \mathrm{M} ; K_{i}$ for pyrithiamine, $1.15 \times 10^{-6} \mathrm{M}$ and for chloroethylthiamine, $5.94 \times 10^{-6} \mathrm{M}$. 
Table 6. Effect of thiamine analogues on ${ }^{35}$ S-thaimine uptake. ${ }^{a}$

\begin{tabular}{lccc}
\hline \multicolumn{1}{c}{ Analogue } & $\begin{array}{c}\text { Molar ratio } \\
\text { to thiamine }\end{array}$ & $\begin{array}{c}\text { Tissue } \\
\text { concentration } \\
(\mu \mathrm{g} / \mathrm{ml} \text { ICF })\end{array}$ & $\begin{array}{c}\text { Per cent } \\
\text { inhibition }\end{array}$ \\
\hline none & - & 0.788 & - \\
Pyrithiamine & 100 & 0.040 & 94.91 \\
Chloroethylthiamine & 10 & 0.100 & 87.28 \\
& 100 & 0.125 & 84.12 \\
Oxythiamine & 10 & 0.363 & 53.92 \\
Thiamine monophosphate & 100 & 0.732 & 7.10 \\
& 10 & 0.687 & 12.82 \\
Thiamine pyrophosphate & 100 & 0.050 & 93.71 \\
& 10 & 0.210 & 73.39 \\
& 100 & 0.049 & 93.82 \\
& 10 & 0.196 & 75.07 \\
\hline
\end{tabular}

a The rat intestinal ring segments were incubated with $0.2 \mu \mathrm{g} / \mathrm{ml}{ }^{35} \mathrm{~S}$-thiamine for $30 \mathrm{~min}$. Other experimental details are described in EXPERIMENTAL.

${ }^{b}$ Each value represents the average from 4 experiments.

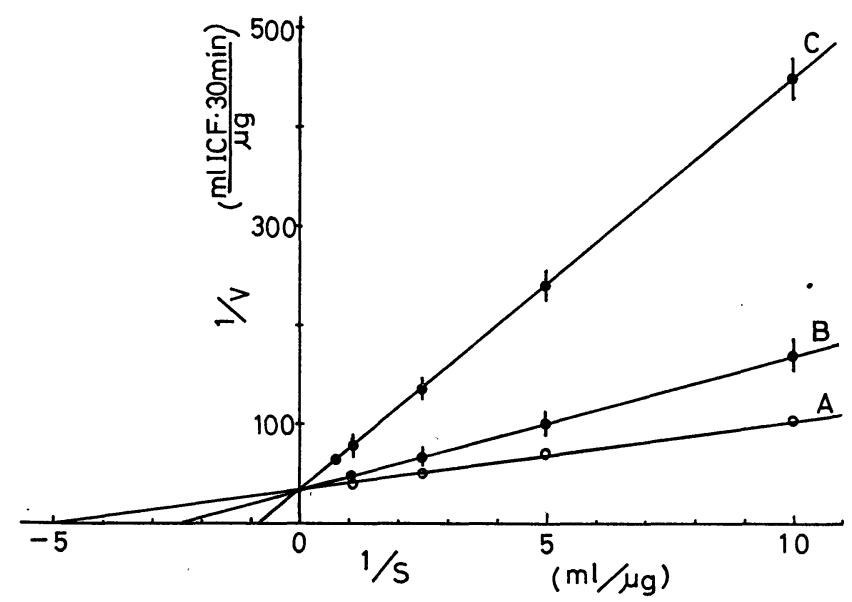

Fig. 5. Lineweaver-Burk reciprocal plot of ${ }^{35} \mathrm{~S}$-thiamine uptake by everted intestinal rings of the rat in the presence and absence of thiamine analogues. The initial medium concentration of ${ }^{35} \dot{S}$-thiamine was $0.1,0.2,0.4,0.9$ and $1.2 \mu \mathrm{g} / \mathrm{ml}$, and the concentration of thiamine analogues was $20 \mu \mathrm{g}$-thiamine equivalent $/ \mathrm{ml}$. A, ${ }^{35}$ S-thiamine alone; B, ${ }^{35}$ S-thiamine + pyrithiamine; C, ${ }^{35}$ S-thiamine + chloroethylthiamine. Each point represents the mean of three determination.

\section{Absorption form of ${ }^{35} S$-thiamine in portal blood}

In order to ascertain the absorption form of ${ }^{35} \mathrm{~S}$-thiamine into portal blood through the epithelial cells of the small intestine, portal blood was collected in situ after injecting ${ }^{35}$ S-thiamine into the intestinal lumen. As shown in Table 7, 
the ratio of ${ }^{35} \mathrm{~S}$-thiamine to total radioactivity in portal blood and in the small intestinal tissue was 43.1 and $58.1 \%$, respectively. This result indicates that a considerable amount of thiamine is absorbed in unchanged form, in accordance with the observation that free thiamine is accumulated in everted segments.

Table 7. Absorption form of ${ }^{35}$ S-thiamine into the portal blood. ${ }^{\mathrm{a}}$

\begin{tabular}{lcc}
\hline & $\begin{array}{c}\text { Free thiamine } \\
(\% \text { of total radioactivity) }\end{array}$ \\
\hline Intestinal tissue & $58.1^{\mathrm{b}}$ & 41.9 \\
Portal blood & 43.1 & 56.9 \\
\hline
\end{tabular}

a ${ }^{35} \mathrm{~S}-T h i a m i n e(10 \mu \mathrm{g})$ was injected into the rat small intestinal loop in situ and absorbed thiamine into the portal vein was collected by cannulation. Other experimental details are described in EXPERIMENTAL.

${ }^{b}$ Each value represents the average from 3 experiments.

Longitudinal distribution of transport activity and thiamine pyrophosphokinase along rat digestive tract

It is supposed that if thiamine pyrophosphokinase participates directly in thiamine transport, the distribution pattern of thiamine transport activity along the digestive tract should coincide with that of thiamine pyrophosphokinase activity. Thus, the relation of the patterns of these activities were examined. As listed in Table 8, thiamine transport activity was the highest at the upper part of the small intestine (jejunum) and the activity of the large intestine was less than $20 \%$ of the activity of the upper small intestine. On the other hand, the difference of thiamine pyrophosphokinase activities among each part of the intestine was not so great as the difference of transport activity, and thiamine pyrophosphokinase activity of the large intestine was $73.5 \%$ of the upper part of the small intestine. These results indicate that the distribution pattern of thiamine pyrophosphokinase did not coincide with that of transport activity.

Table 8. Longitudinal distribution of transport activity of thiamine and thiamine pyrophosphokinase activity along rat digestive tract.

\begin{tabular}{|c|c|c|c|c|c|}
\hline Digestive tract & $\begin{array}{l}\text { Transport a } \\
\text { Concentration } \\
(\mu \mathrm{g} / \mathrm{ml} \text { ICF })\end{array}$ & $\begin{array}{l}\text { ctivity of }{ }^{35} \mathrm{~S}-\text { th } \\
\quad \text { Ratio } \\
\left(C_{\left.\mathrm{ICF} / C_{\mathrm{ECF}}\right)}\right.\end{array}$ & $\begin{array}{l}\text { niamine } \\
(\%)\end{array}$ & $\begin{array}{l}\text { Thiamine pyro- } \\
\text { phosphokinase activity } \\
(\mathrm{m} \mu \text { moles of TPP })^{2}\end{array}$ & y $(\%)$ \\
\hline Duodenum & 0.687 & 3.47 & 88.3 & 7.60 & 95.7 \\
\hline Jejunum & 0.767 & 3.93 & 100 & 7.95 & 100 \\
\hline Upper ileum & 0.510 & 2.60 & 66.2 & 6.48 & 81.5 \\
\hline Lower ileum & 0.363 & 1.89 & 48.1 & 5.04 & 63.4 \\
\hline Large intestine & 0.147 & 0.76 & 19.3 & 5.85 & 73.5 \\
\hline
\end{tabular}

a TPP, Thiamine pyrophosphate.

Experimental details are described in EXPERIMENTAL. 
Subcellular distribution of thiamine pyrophosphokinase in rat intestinal mucosa

The intestinal mucosa were separated into three fractions; mitochondria, microsomes and soluble fraction. As listed in Table 9, the activity of leucine aminopeptidase, one of marker enzymes of the microvillous membrane, was detected almost exclusively in mitochondria and microsomes. On the other hand, thiamine pyrophosphokinase activity detected in a soluble fraction. There exists very little activity of thiamine pyrophosphokinase in mitochondria and microsomes in which most of the microvillous membrane was contained. Therefore, it is unlikely that this enzyme plays a direct role in the thiamine active transport.

Table 9. Subcellular distribution of thiamine pyrophosphokinase in rat intestinal mucosa. ${ }^{a}$

\begin{tabular}{|c|c|c|c|c|}
\hline \multirow[b]{2}{*}{ Subcellular fraction } & \multicolumn{2}{|c|}{ Thiamine pyrophosphokinase } & \multicolumn{2}{|c|}{ Leucine aminopeptidase } \\
\hline & $\begin{array}{c}\text { (m } \mu \text { moles of formed) } \\
\text { TPP }^{b}\end{array}$ & $(\%)$ & $\begin{array}{c}\text { (Goldbarg-Rutenburg) } \\
\text { unit }\end{array}$ & $(\%)$ \\
\hline Mitochondria & 0 & 0 & 1450 & 40.27 \\
\hline Microsomes & 0.0003 & 11.28 & 1856 & 51.54 \\
\hline Soluble fraction & 0.0232 & 98.72 & 295 & 8.19 \\
\hline \multicolumn{5}{|c|}{$\begin{array}{l}\text { The intestinal mucosa was homogenized in } 0.25 \mathrm{~m} \text { sucrose solution followed by centri- } \\
\text { fugation. For determination of thiamine pyrophosphokinase of each fraction, }{ }^{35} \mathrm{~S}- \\
\text { thiamine was used as a substrate. Other experimental details are described in Ex- } \\
\text { PERIMENTAL. }\end{array}$} \\
\hline
\end{tabular}

\section{DISCUSSION}

In the previous paper (2), it was proved by means of tissue accumulation method that thiamine is absorbed from the chick small intestine by active transport. While in regard to thiamine absorption from the rat small intestine, it has been examined so far only in vitro by the everted sac method. In this paper, thiamine absorption from the rat small intestine was kinetically investigated by means of the tissue accumulation method.

Prior to the investigation of the absorption mechanism of thiamine at a low concentration, the in vitro everted sac technique was reevaluated by the examination of thiamine movement through the sac. As the result, it was shown that thiamine was accumulated in a high concentration by the tissue and that it took very long time until thiamine was detected in the serosal fluid. In the efflux process into the serosal fluid, thiamine must penetrate through the many barriers such as submucous layer or muscular layers. However, thiamine taken up by the intestinal tissue is absorbed in vivo directly into the venous capillaries which situate under the epithelial cells, and scarcely penetrate through the serosal barriers. Besides, it is well known that the absorptive functions exist in the epithelial lining 
cells, especially in the microvillous membrane of the absorptive cells. Thus, it was concluded that the tissue accumulation method, in which the substances transported from the medium to the tissue segments are directly determined, is more convenient than the everted sac technique. The histological examination of tissue preservation also supported the superiority of the tissue accumulation method.

From the present results, it was clearly shown that thiamine is transported into rat intestinal segments by an active transport mechanism and accumulated in the tissue as free thiamine to a considerable extent as well as its phosphates. After $30 \mathrm{~min}$ incubation in the medium containing $0.2 \mu \mathrm{g} / \mathrm{ml}$ of ${ }^{35} \mathrm{~S}$-thiamine, the intracellular to extracellular concentration ratio was found to be 5.05 with respect to the total thiamine and 2.27 with respect to free thiamine, indicating a transport of free thiamine against a concentration gradient. All of the other requirements for the concept of an active transport, that is, the saturation kinetics, the temperature dependency, the energy requirement and the competitive inhibition by structural analogues, were also found to be filled for the thiamine transport.

Hoyumpa (11) also has observed from in situ experiments that thiamine absorption from the rat ligated intestine is saturable, particulary at a low concentration of thiamine.

It has been often suggested that thiamine pyrophosphokinase plays an important role in an active transport of thiamine. However, in addition to the fact that free thiamine was accumulated in the intestinal tissue higher than the medium concentration, it was shown that chloroethylthiamine, which did not affect thiamine pyrophosphokinase activity at all (2), inhibited thiamine transport. Moreover, the longitudinal distribution of thiamine pyrophosphokinase along the digestive tract did not coincide with that of the activity of thiamine uptake. Then, thiamine pyrophosphokinase was scarcely detected in the fraction of microvillous membrane. This evidence indicates strongly that there is a specific carrier system for the transport of thiamine which is, irrespective of the phosphorylation process, just like the absorption mechanism of thiamine from the chick intestine (2).

With respect to elucidation of the indirect role of phosphorylation in thiamine absorption, it seems to be very important to examine the phosphorylation of thiamine taken up by the intestinal tissues under various conditions.

In the subsequent paper, the structural specificity for thiamine transport by the small intestine will be examined and discussed.

The authors express their deep gratitude to Dr. G. Sunagawa, director of this laboratories, for his valuable advice and encouragement. Thanks are also due to Miss M. Matsumura of this laboratories for her technical assistance. This work was done in partial satisfaction of the requirement for the Ph.D. degree of T. Komai from Kyoto University. 


\section{REFERENCES}

1) Morrison, S. K. and CAmpbell, J. A., J. Nutri., 72, 435 (1960).

2) Komar, T. and Shindo, H., J. Vitaminol., 18, 55 (1972).

3) Ventura, U. and Rindi, G., Experientia, 21, 645 (1965).

4) RINDI, G. and Ventura, U., Experientia, 23, 175 (1967).

5) Ventura, U., Ferrari, G., Tagliabue, R., and Rindi, G., Life Sci., 8, 699 (1969).'

6) Agar, W. T., Hird, F. J. R., and Sidhu, G. S., Biochim. Biophys. Acta, 14, 80 (1954).

7) Matsukawa, T. and Iwatsu, T., J. Pharm. Soc. Japan (in Japanese), 71, 720 (1951).

8) YoshidA, S. and UnokI, M., J. Pharm. Soc. Japan (in Japanese), 72, 1431 (1951).

9) Krebs, H. A. and Henseleit, K., Hoppe-Seyl. Z., 210, 33 (1932).

10) Levine, R. R., McNary, W. F., Kornguth, P. J., and Leblanc, R., Europ. J. Pharmacol., 9, 211 (1970).

11) Hoyumpa, A., personal communication. 